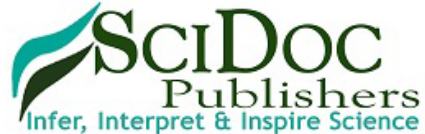

\section{Comparison Of Autogenous Iliac Bone Grafting with PRP And Conventional Iliac Bone Grafting In Alveolar Bone Grafting - A Systematic Review}

\author{
International Journal of Dentistry and Oral Science (IJDOS) \\ ISSN: $2377-8075$
}

Research Article

Ashutosh Deshpande ${ }^{1 *}$, Hemavathy $\mathrm{OR}^{2}$, Sneha Krishnan ${ }^{3}$

${ }^{1}$ Department of Oral and Maxillofacial Surgery, Saveetha Dental College, SIMATS, Saveetha University, Chennai 77, India.

${ }^{2}$ Professor, Department of Oral and Maxillofacial Surgery, Saveetha Dental College, SIMATS, Saveetha University, Chennai 77, India.

${ }^{3}$ Department of Oral and Maxillofacial Surgery, Saveetha Dental College, SIMATS, Saveetha University, Chennai 77, India.

\title{
Abstract
}

Background: Clefts of the lip, palate and alveolus are the most commonly seen congenital deformities which affect the maxillofacial region. Efforts have been made to classify and repair, since the time of Veau (1931). Repair of cleft alveolus is an adjunctive procedure to further improve the functional and esthetic rehabilitation of patient with unilateral or bilateral cleft lip and palate, and to provide bone for eruption of the canine so that the canine teeth will erupt into the mouth with good bone support and remain healthy during the mixed dentition period.[1] Currently, the use of platelet rich plasma (PRP) in alveolar bone grafting procedures is of greater interest to enhance bone formation and specifically to enhance the bone healing.[2] Use of PRP is based on the theory that its platelets release statistically significant quantities of growth factors to facilitate the maturation of the bone graft. Also, PRP acts as a fibrin adhesive. [3] The adhesive property of PRP helps in haemostasis and flap adaptations. PRP also reduces the chances of infection, due to its acidic nature, The chances of infection are further reduced, as PRP concentrates WBC's and platelets to cause early neovascularization, bring in circulating macrophages and neutrophils and create a more oxygen rich environment. The current concept of growth factor-aided tissue engineering with regard to reconstruction of the cleft alveolous is to use bone morphogenetic protein (BMP), transforming growth factor beta, platelet-derived growth factor, insulin-like growth factor, fibroblast growth factor, vascular endothelial growth factor and PRP. [4] It is interesting to know that biphasic calcium phosphate (BCP) mixed with autologous bone has not been found to interfere with dental eruption or maxillary growth. [5] Closure of wide alveolar clefts using mid face distraction has been reported as an alternative treatment modality. [6] This systematic review is to compare the efficacy of alveolar bone reconstruction for alveolar cleft patients surgically treated with the traditional iliac graft and the iliac bone graft with PRP. Electronic databases, relevant journals, and reference lists of the included studies were searched till the end of OCT 2019 with an aim to evaluate the efficacy of PRP for secondary alveolar bone graft procedure.

Objectives: The objective of this systematic review is to analyze the comparison of autogenous iliac bone grafting with PRP and conventional iliac bone graft in alveolar bone grafting.

Data Sources: The Data Bases of PubMed, Cochrane and Google scholar were searched for the related topics along with a complimentary manual search of all oral surgery journals till October 2019. Articles were selected based on the inclusion criteria, which included all RCTs.

Results: From this study we conclude that PRP in addition to autogenous iliac bone graft is effective in early bone formation and reduction in bone resorption rate.

Conclusion: The addition of PRP to autogenous iliac bone grafts helps in early bone formation, reduces postoperative bone resorption, PRP may preserve the width, height of the graft, low infection rate and least post operative complications that makes autogenous cancellous bone grafting with PRP useful for alveolar bone grafting in cleft patients.

\section{Introduction}

Clefts of the lip, palate and alveolus are the most commonly seen congenital deformities which affect the maxillofacial region. Efforts have been made to classify and repair, since the time of Veau (1931)[1] alveolar bone grafting has become accepted as a means of uniting and stabilizing the segments of the maxilla prior to definitive orthodontic and restorative dental treatment [7].

In some cleft patients, the bone defect is due to the width between the maxillary segments, or as a result of bone resorption [8-10]. A method for reducing bone resorption in alveolar cleft

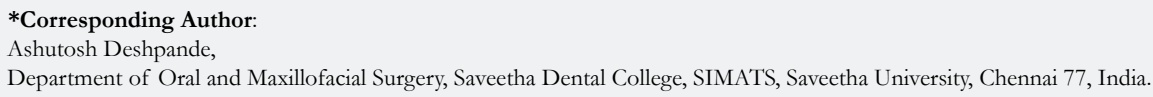

Citation: Ashutosh Deshpande, Hemavathy OR, Sneha Krishnan. Comparison Of Autogenous Iliac Bone Grafting with PRP And Conventional Iliac Bone Grafting In Alveolar Bone Grafting - A Systematic Review. Int J Dentistry Oral Sci. 2021;8(7):3323-3329. doi: http://dx.doi.org/10.19070/2377-8075-21000677

Copyright: Ashutosh Deshpande ${ }^{2021}$. This is an open-access article distributed under the terms of the Creative Commons Attribution License, which permits unrestricted use, distribution and reproduction in any medium, provided the original author and source are credited. 
bone grafting has been used for some time. In 1998, platelet-rich plasma (PRP) was reported to promote new bone formation in mandibular continuity defects and to cause faster maturation of autologous bone grafts.[11] Also, PRP acts as a fibrin adhesive.3 The adhesive property of PRP helps in haemostasis and flap adaptations. PRP also reduces the chances of infection, due to its acidic nature. The chances of infection are further reduced, as PRP concentrates WBC's and platelets to cause early neovascularization, bring in circulating macrophages and neutrophils and create a more oxygen rich environment. The current concept of growth factor-aided tissue engineering with regard to reconstruction of the cleft alveolous is to use bone morphogenetic protein (BMP), transforming growth factor beta, platelet-derived growth factor, insulin-like growth factor, fibroblast growth factor, vascular endothelial growth factor and PRP.[4]

It is interesting to know that biphasic calcium phosphate (BCP) mixed with autologous bone does not interfere with dental eruption or maxillary growth.[5] Closure of wide alveolar clefts using mid face distraction has been reported as an alternative treatment modality.[6]

This systematic review is to compare the efficacy of alveolar bone reconstruction for alveolar cleft patients performed with the traditional iliac graft and the iliac bone graft with PRP. Electronic databases, relevant journals, and reference lists of the included studies were searched to the end of OCT 2019 with an aim to evaluate the efficacy of PRP for secondary alveolar bone graft procedure.

\section{Aim}

The aim of this systematic review was to analyse the existing literature to assess the efficacy autogenous iliac bone graft with PRP in comparison to iliac bone graft alone in case of alveolar bone grafting.

\section{Structured Question}

Does PRP in combination with autogenous iliac bone graft is enhance the bone regeneration in comparison with iliac bone graft alone?

\section{PICO Analysis}

Population: Patients undergoing alveolar grafting surgery

Intervention: PRP in combination with autogenous iliac bone graft.

Comparison: Conventional iliac bone graft.

Outcome:Quantitative bone regeneration.

\section{Materials And Methods}

\section{Inclusion Criteria}

Criteria for considering studies for the Review -

Types of studies -

- Randomized controlled trials

- Clinical trials.
- Longitudinal studies

\section{Types of Participants -}

- Patients undergoing Alveolar bone grafting surgery

\section{Types of Intervention}

- PRP with autogenous bone graft in alveolar bone grafting surgery

\section{Types of Comparison}

- Conventional autogenous bone graft alone.

\section{Types of Outcome Measures}

- Quantitative Bone formation assessed on the basis of CT or CBCT or Computer Aided Engineering evaluation.

\section{Exclusion Criteria}

The following studies were excluded,

- Review articles

- Animal studies

- Invitro studies

- Studies not meeting inclusion criteria

- Languages other than English

\section{Sources Used}

The Data Bases of PubMed, Cochrane and Google scholar were searched for the related topics.

We used free-text terms to search the following journals"

- British Journal of Oral and Maxillofacial Surgery.

- International Journal of Oral and Maxillofacial Surgery.

- Journal of Oral and Maxillofacial Surgery.

- Journal of Cranio Maxillofacial Surgery.

Only articles in English and human species were applied during the electronic search to include all the possible clinical trials that are relevant for the search phase of the systematic review. Reference list of the identified randomized trials were also checked for possible additional studies.

\section{Search Flow Chart}

Flow Chart

\section{Data Collection And Analysis}

\section{Screening and Selection}

Electronic search was carried out using the keywords in the Search engines- PubMed, Cochrane and manual search which yielded a total of 5 articles. Based on pre-set inclusion and exclusion criteria, the titles of the studies identified from the search were assessed independently by two review authors (Dr. Ashu- 
tosh Deshpande, Dr.Hemavathy .O R) Conflicts concerning inclusion of the studies were resolved by discussion. Seventy three articles were excluded after reading titles. Two titles were identified from the search after excluding Four duplication. Abstracts of selected articles were reviewed independently. No articles were excluded after reading abstract. Full text articles were retrieved for two relevant studies.

The reference list of the full text articles were reviewed for identifying additional studies. Titles of articles relevant to the review were selected by discussion. Quality Assessment criteria to evaluate the studies were decided by two review authors in accordance with CONSORT guidelines. The risk of bias for each study was independently assessed by the review authors and conflicts concerning risk of bias were sorted by discussion.

\section{Data Extraction}

Data extraction for general characteristics of studies and variables of outcome was done.

For each trial the following data were recorded:

- Author and Journal

- Study Design

- Sample Size

- Participants and Group

- Methodology

- Outcome measures

- Results

- Conclusion

\section{PRISMA Flow Diagram.}

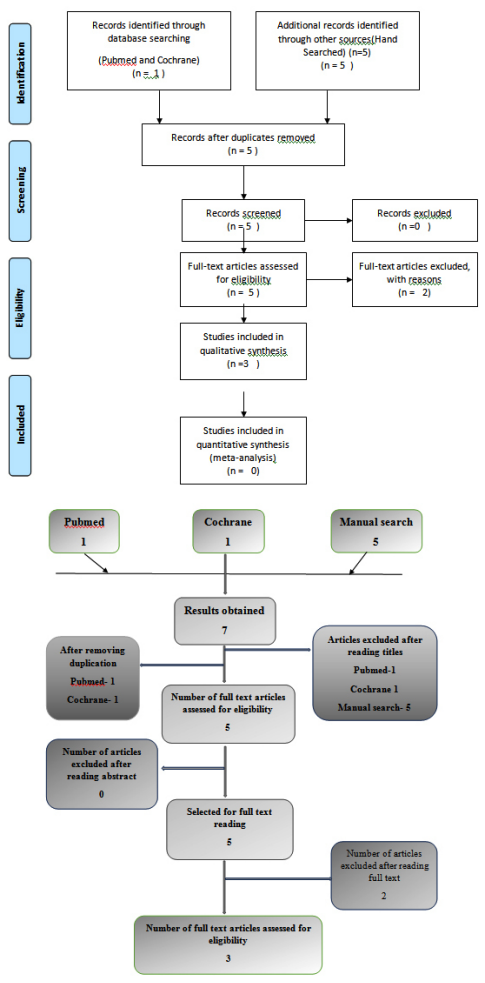

Table 1. Variables Of Interest.

\begin{tabular}{|c|c|}
\hline S.No & VARIABLES OF INTEREST \\
\hline 1 & Quantitative evaluation of bone formation \\
\hline
\end{tabular}

Table 2. General Characteristics Of The Studies.

\begin{tabular}{|c|c|c|c|c|c|c|c|}
\hline S.No & Author & Year & Study design & Sample size & Age & Technique Used & Method of Evaluation \\
\hline \multirow{2}{*}{1} & $\begin{array}{l}\text { Efficacy of Platelet-Rich Plasma } \\
\text { in }\end{array}$ & \multirow{2}{*}{2004} & \multirow{2}{*}{$\begin{array}{l}\text { Randomized } \\
\text { controlled trial }\end{array}$} & \multirow{2}{*}{$\mathrm{N}=12$} & \multirow{2}{*}{$16-18 \mathrm{yrs}$} & \multirow{2}{*}{$\begin{array}{l}\text { One group receiving PRP } \\
\text { with iliac bone graft and an- } \\
\text { other iliac bone graft alone }\end{array}$} & \multirow{2}{*}{$\begin{array}{c}\text { Quantitative bone forma- } \\
\text { tion was evaluated by CT } \\
\text { evaluation }\end{array}$} \\
\hline & $\begin{array}{l}\text { Alveolar Bone Grafting by Tomo- } \\
\text { ki Oyama et al }\end{array}$ & & & & & & \\
\hline 2 & $\begin{array}{l}\text { Alveolar bone graft with Platelet } \\
\text { Rich Plasma in cleft alveolus } \\
\text { byChandan Gupta et al }\end{array}$ & 2013 & $\begin{array}{l}\text { Randomized } \\
\text { controlled trial }\end{array}$ & $\mathrm{N}=20$ & $9-29 y r s$ & $\begin{array}{l}\text { One group receiving PRP } \\
\text { with iliac bone graft and an- } \\
\text { other iliac bone graft alone }\end{array}$ & $\begin{array}{l}\text { Quantitative bone forma- } \\
\text { tion was evaluated by cbct } \\
\text { evaluation }\end{array}$ \\
\hline \multirow{2}{*}{3} & $\begin{array}{c}\text { Effect of Platelet-Rich Plasma on } \\
\text { Bone Grafting of }\end{array}$ & \multirow{2}{*}{2016} & \multirow{2}{*}{$\begin{array}{l}\text { Randomised } \\
\text { double blinded } \\
\text { clinical study }\end{array}$} & \multirow{2}{*}{$\mathrm{N}=29$} & \multirow{2}{*}{$7-9 \mathrm{yrs}$} & \multirow{2}{*}{$\begin{array}{l}\text { One group receiving PRP } \\
\text { with iliac bone graft and an- } \\
\text { other iliac bone graft alone }\end{array}$} & \multirow{2}{*}{$\begin{array}{l}\text { Quantitative bone } \\
\text { formation was evaluat- } \\
\text { ed by computer-aided } \\
\text { engineering. }\end{array}$} \\
\hline & $\begin{array}{c}\text { Alveolar Clefts by Reiko Sakio } \\
\text { et al }\end{array}$ & & & & & & \\
\hline
\end{tabular}


Table 3. Data Extraction Table.

\begin{tabular}{|c|c|c|c|c|c|}
\hline Sr.No & Author and year & Technique used & Method of evaluation & Statistics & Outcomes \\
\hline 1 & $\begin{array}{c}\text { Efficacy of Plate- } \\
\text { let-Rich Plasma in } \\
\text { Alveolar Bone Graft- } \\
\text { ing by Tomoki Oyama } \\
\text { et al, } 2004\end{array}$ & $\begin{array}{c}\text { Alveolar bone } \\
\text { grafting using } \\
\text { iliac bone graft } \\
\text { with and without } \\
\text { PRP }\end{array}$ & $\begin{array}{l}\text { Quantitative bone for- } \\
\text { mation was evaluated } \\
\text { by CT evaluation }\end{array}$ & $\begin{array}{c}\text { The ratio of volume of } \\
\text { alveolar cleft to volume } \\
\text { of regenerated bone } \\
\text { was } \\
\text { PRP: } 80.19 \% \pm 6.77 \% \\
\text { [SD] } \\
\text { Non- PRP: } 63.67 \% \pm \\
13.94 \%[S D]\end{array}$ & $\begin{array}{l}\text { PRP was a safe and cost-effective } \\
\text { source for growth factors and was } \\
\text { easy to extract. It } \\
\text { could enhance the osteogenesis of } \\
\text { alveolar bone grafting in cleft lip and } \\
\text { palate patients and may useful } \\
\text { for subsequent orthodontic therapy }\end{array}$ \\
\hline 2 & $\begin{array}{l}\text { Alveolar bone graft } \\
\text { with Platelet Rich } \\
\text { Plasma in cleft alveo- } \\
\text { lus byChandan Gupta } \\
\text { et al, } 2013\end{array}$ & $\begin{array}{c}\text { Alveolar bone } \\
\text { grafting using } \\
\text { iliac bone graft } \\
\text { with and without } \\
\text { PRP }\end{array}$ & $\begin{array}{l}\text { Quantitative bone for- } \\
\text { mation was evaluated } \\
\text { by cbct evaluation }\end{array}$ & $\begin{array}{c}\text { The mean bone density } \\
\text { after } 6 \text { months } \\
\text { PRP : } 1028.00 \_11.30 \\
\text { HU } \\
\text { Non PRP: } \\
\text { 859.50_27.73HU }\end{array}$ & $\begin{array}{c}\text { A statistically significant improvement } \\
\text { in the density was } \\
\text { found. }\end{array}$ \\
\hline 3 & $\begin{array}{c}\text { Effect of Platelet-Rich } \\
\text { Plasma on Bone } \\
\text { Grafting of } \\
\text { Alveolar Clefts by } \\
\text { Reiko Sakio et al, } 2016\end{array}$ & $\begin{array}{c}\text { Alveolar bone } \\
\text { grafting using } \\
\text { iliac bone graft } \\
\text { with and without } \\
\text { PRP }\end{array}$ & $\begin{array}{l}\text { Quantitative bone for- } \\
\text { mation was evaluated } \\
\text { by computer-aided } \\
\text { engineering. }\end{array}$ & $\begin{array}{c}\text { The mean volume of } \\
\text { bone formation @ } \\
\text { 1year } \\
\text { PRP: 0.55_0.44 } \\
\text { Non PRP: 0.59_0.28 } \\
\text { cm3, }\end{array}$ & No significant difference was found \\
\hline
\end{tabular}

Table 4. Evidence Level Of Selected Articles.

\begin{tabular}{|c|c|c|c|}
\hline SI No & Author and year & Study design & Level of Evidence \\
\hline 1 & $\begin{array}{c}\text { Efficacy of Platelet-Rich Plasma in } \\
\text { Alveolar Bone Grafting by Tomoki Oyama et al, 2004 }\end{array}$ & $\begin{array}{c}\text { Randomized } \\
\text { controlled trial }\end{array}$ & 1 \\
\hline 2 & $\begin{array}{c}\text { Alveolar bone graft with Platelet Rich Plasma in cleft alveo- } \\
\text { lus byChandan Gupta et al, 2013 }\end{array}$ & $\begin{array}{c}\text { Randomized } \\
\text { controlled trial }\end{array}$ & 1 \\
\hline 3 & $\begin{array}{c}\text { Effect of Platelet-Rich Plasma on Bone Grafting of } \\
\text { Alveolar Clefts by Reiko Sakio et al, 2016 }\end{array}$ & $\begin{array}{c}\text { Randomized } \\
\text { controlled trial }\end{array}$ & 1 \\
\hline
\end{tabular}

Table 5. Risk Of Bias- Major Criteria.

\begin{tabular}{|c|c|c|c|c|c|c|}
\hline S.No & Study & $\begin{array}{c}\text { Random- } \\
\text { ization }\end{array}$ & $\begin{array}{c}\text { Allocation } \\
\text { concealment }\end{array}$ & $\begin{array}{c}\text { Assessor } \\
\text { Blinded }\end{array}$ & $\begin{array}{c}\text { Drop outs } \\
\text { described }\end{array}$ & $\begin{array}{c}\text { Risk of } \\
\text { Bias }\end{array}$ \\
\hline 1 & $\begin{array}{c}\text { Efficacy of Platelet-Rich Plasma in Al- } \\
\text { veolar Bone Grafting by Tomoki Oyama } \\
\text { et al, 2004 }\end{array}$ & yes & Yes & Yes & None & Moderate \\
\hline 2 & $\begin{array}{c}\text { Alveolar bone graft with Platelet Rich } \\
\text { Plasma in cleft alveolus byChandan Gup- } \\
\text { ta et al, 2013 }\end{array}$ & Yes & yes & Yes & None & Low \\
\hline 3 & $\begin{array}{c}\text { Effect of Platelet-Rich Plasma on Bone } \\
\text { Grafting of Alveolar Clefts by Reiko } \\
\text { Sakio et al, 2016 }\end{array}$ & Yes & yes & yes & None & Low \\
\hline
\end{tabular}

Table 6. Risk Of Bias-Minor Criteria.

\begin{tabular}{|c|c|c|c|c|c|}
\hline S.No & STUDY & $\begin{array}{c}\text { SAMPLE JUSTI- } \\
\text { FIED }\end{array}$ & $\begin{array}{c}\text { BASELINE COM- } \\
\text { PARISON }\end{array}$ & I/E CRITERIA & METHOD OF ERROR \\
\hline 1 & $\begin{array}{c}\text { Efficacy of Platelet-Rich } \\
\text { Plasma in } \\
\text { Alveolar Bone Grafting by } \\
\text { Tomoki Oyama et al, 2004 }\end{array}$ & Yes & Yes & Yes & No \\
\hline 2 & $\begin{array}{c}\text { Alveolar bone graft with } \\
\text { Platelet Rich Plasma in cleft } \\
\text { alveolus byChandan Gupta et } \\
\text { al, 2013 }\end{array}$ & Yes & Yes & Yes & No \\
\hline 3 & $\begin{array}{c}\text { Effect of Platelet-Rich Plasma } \\
\text { on Bone Grafting of } \\
\text { Alveolar Clefts by Reiko Sakio } \\
\text { et al, 2016 }\end{array}$ & Yes & Yes & Yes & No \\
\hline
\end{tabular}


Table 7. Summation Table For Individual Parameter.

\begin{tabular}{|c|c|c|c|c|}
\hline S.No & Author & Year & Evaluation period & Outcome \\
\hline 1 & $\begin{array}{c}\text { Efficacy of Platelet-Rich Plas- } \\
\text { ma in Alveolar Bone Grafting } \\
\text { by Tomoki }\end{array}$ & 2004 & 1 month, 6 month & $\begin{array}{c}\text { There was significant difference } \\
\text { between two groups, results are in } \\
\text { favour of PRP group }\end{array}$ \\
\hline 2 & $\begin{array}{c}\text { Alveolar bone graft with Plate- } \\
\text { let Rich Plasma in cleft alveolus } \\
\text { byChandan Gupta et al, 2013 }\end{array}$ & 2013 & $\begin{array}{c}1 \text { month, 3 months, } \\
6 \text { months }\end{array}$ & $\begin{array}{c}\text { There was significant difference } \\
\text { between two groups, results are in } \\
\text { favour of PRP group }\end{array}$ \\
\hline 3 & $\begin{array}{c}\text { Effect of Platelet-Rich Plasma } \\
\text { on Bone Grafting of } \\
\text { Alveolar Clefts by Reiko Sakio } \\
\text { et al, 2016 }\end{array}$ & 2016 & 1 month, 12 months & $\begin{array}{c}\text { No statistically significant } \\
\text { difference }\end{array}$ \\
\hline
\end{tabular}

\section{Quality Assessment}

(Higgins and Green. Cochrane reviewer's hand book 2009)

The quality assessment of included trials was undertaken independently as a part of data extraction process. Four main quality criteria were examined.

1. Method of Randomization, recorded as

a) YES- Adequate as described in the text

b) NO- Inadequate as described in the text

c) Unclear in the text

2. Allocation Concealment, recorded as

a) YES- Adequate as described in the text

b) NO- Inadequate as described in the text

c) Unclear in the text

3. Outcome assessors Blinded to intervention, recorded as

a) YES- Adequate as described in the text

b) NO- Inadequate as described in the text

c) Unclear in the text

4. Completeness of Follow up (was there a clear explanation for withdrawals and dropouts in each treatment group) assessed as

a) YES- Dropouts were explained

b) NO- Dropouts were not explained

c) None- No Dropouts or withdrawals.

Other methodological criteria examined included:

1. Presence or Absence of sample size calculation.

2. Comparability of Groups at the start.

3. Clear Inclusion or Exclusion criteria.

4. Presence or Absence of estimate of measurement error.

\section{Risk Of Bias In Included Studies}

The study was assessed to have a "High risk" of bias if it did not record a "Yes" in three or more of the four main categories, "Moderate Risk "if two out of four categories did not record a "Yes", and "Low Risk" if all the four categories recorded if randomization assessor, Blinding and Completeness of follow up were considered Adequate. In case of non-randomized and clinical trials without control group, it is recorded as not applicable.
Results

Tables.

\section{Discussion}

Alveolar bone grafting is a definitive treatment in case of Alvelolar clefts. It may not only bring about eruption of the tooth but also plays an important role in stabilizing the maxillary arch. Also provides the bone for the dental implants in patients with missing teeth.[12-15] Iliac cancellous bone is the graft of choice, because it is easy to harvest and provides sufficient amount of bone required for alveolar bone grafting and shows better osteoinduction as compared to other grafts.However, partial absorption and shortage of reconstructed alveolar height or width may develop postoperatively in case of conventional iliac graft.

It is believed that PRP has osteogenic growth potential and could promote the formation of bone in alveolar bone grafting, reduce resorption of graft in cleft lip and palate patients, and may be useful for further orthodontic treatment. It is said that PRP might enhance the osteogenesis of autologous bone and lessen postoperative bone resorption. [15]

According to Oyama et al, 2004, PRP might increase the osteogenic potential of autologous bone and reduces the postoperative resorption of the bone. In this study, Seven patients in tertiary stage, were grafted with PRP, acquired a markedly high capacity rate of regenerated bone, which was significantly different from controls. Schmitz and Hollinger [16] doubt the effects of PRP because platelet-derived growth factor is inhibitory to osteoblastic cells if delivered in a continuous form and increases bone resorption. In this study, PRP could enhance the bone formation more than the bone resorption in a phase of bone remodeling within 6 months postoperatively. However, it is not known for how long (>6months) PRP exerts an influence on the bone volume in this study. Without functional stress in the graft, atrophic bone resorption would occur in the long term.[17]

Marx et al11 reported successful results of the mandibular segment reconstruction with PRP.

In that article bone density was measured with the help of $\mathrm{x}$ ray films and a quantitative analysis was done. Oyama et al, have measured the volume of regenerated bone (VRB)with 3D CT. However, in his study, they have not assessed the bone density. A standard method of alveolar bone grafting evaluation has not been established as yet which includes both qualitative and quantitative evaluation. According to Oyama et al, the biologically appropriate concentration of growth factors involved in PRP is still 
unknown.

In the study by C. Gupta et al, 2013, 20 patients with alveolar cleft, in the age group of 8 to 30 years, with unilateral or bilateral cleft lip and palate were selected for the sudy. The patients were randomly divided into two groups, the test group A (10 patients) received cancellous bone graft from the anterior iliac crest mixed with PRP, while the control group B (10 patients) received the same without PRP. Alveolar bone grafting was performed under GA using standard surgical methodology for secondary alveolar bone grafting. Bone density of the grafted bone was assessed with Dentascan, using pixel tools image analyzer software, at regular postoperative follow up of 1,3 and 6 months.

PRP primarily has acidic $\mathrm{pH}$ (6.5 to 6.7) inhibits bacterial colony growth. Secondarily, PRP concentrates WBCs and platelets to cause bacterial inhibition by greater number of functionaly viable leucocytes. Thirdly, rapid development of granulation tissue by early in-growth of capillaries prevents bacterial growth by bringing in circulating macrophages and neutrophils. Thus, creating an oxygen rich environment suppresses the growth of anaerobic micro-organisms. In our study, bone chips were harvested from the anterior iliac crest using trephine method and none of the patients reported any complications. Bone graft studies using autogenous marrow from the ilium have shown capillary in-growth within 5 to 6 days without PRP versus 3 days with PRP and complete revascularization by 20 days without PRP versus 14 days with PRP.

Studies by Marx [11] provide evidence that PRP added to grounded bone graft obtained from posterior iliac crest showed increase in the rate of bone formation. Results suggest that growth factors are helpful in accelerating and intensifying regeneration of the alveolar bone. Luaces-Rey [21] found no significant differences between both therapeutic groups on bone regeneration based on digital orthopantomogram, 1 to 6 months after surgery. It has been reported that there is increase in bone mineral density grafts combined with PRP ranging from 1.6 to 2.2 times that of a grafts without PRP,11 as seen in our study. However, Lee [22] suggested that PRP may cause in crease in the bone remodeling in the initial phase, it seems to be insufficient as a counter measure against bone resorption following secondary bone graft in the long term. Macisaac used supplemental demineralized bone matrix and allograft, and observed complete canine eruption in $71.4 \%$, partial in 21.4 , and unerupted in $3.5 \%$ [23].

The limitation of this study was a short follow up of 6 months, hence only the early results could be compared.

In a study by Sakio et al, 2016, they analyzed the regeneration of the bone using computer aided engineering by 3D CT. In this study they have assumed that the osteogenic activity of the autologous bone graft increases with the help of PRP and there is reduction in post operative bone resorption; However, But there sults of the quantitative analysis of the graft sites show that the mean remaining bone was no significant difference between with and without PRP groups at 1 year after surgery.

Recent meta-analysis literatures described about the effect of PRP based on human studies was said that there was a scientific evidence regarding favorable outcomes of the use of PRP for the treatment of diabetic ulcer.[25]; However, tendon healing and bone graft for cleft lip and palate was inconclusive of the effect of PRP for the maxillary sinus lift [26-28].

Osteoprotegrin which is a soluble receptor secreted by many cell types including osteoblasts. This factor is an inhibitory factor for the osteoclastoogenesis24. To consider about the osteoregeneration, new bone formation at bone resorption sites in each cycle of bone remodeling to maintain the micro-architecture required for bone's mechanical properties. The platelet-derived growth factor causes stimulation of osteoprotegerin which is an inhibitor of osteoclast and produced in osteoblastic cells. It seems that inhibition of osteoclast will inhibit the resorption of the bone. TGFb-1 is activated in response to osteoclastic bone resorption. [29] But the osteoclast is inhibited by the osteoprotegerin. So not only the bone resorption does not occur but also the TGFb-1 cannot be activated. This can be one reason that the remaining bone ratio was not significant in both the groups. One of the important technologies is to achieve the controlled release of growth factors at the necessary site for clinical applications of growth factors present in PRP. In an animal study it was stated that gelatin hydrogel is needed to achieve the controlled release of bioactive factors from PRP;[30] However, can not be applied clinically.

PRP gel provides both valuable growth factors and haemostatic adhesion to the wound, which does not enhance the healing process by the postoperative bone resorption directly, but minor wound dehiscence which influenced the bone infections and resorption could be closed early. This indirectly results into prevention of the bone resorption. The biological mechanism of the PRP s still unknown16 and more studies have to be conducted.

\section{Interpreatation Of Results}

In the study conducted by Oyama et al,2004, of bonegrafting added with PRP, the minimum percentage ofVRB/VAC was $71.27 \%$ (patient 6 ) and the maximumwas $87.32 \%$ (patient 2) (average, $80.19 \%$ _ $6.77 \%[\mathrm{SD}])$. In control group the minimum percentage of VRB/VACwas $47.47 \%$ (patient 9) and the maximum was $77.97 \%$ (patient 10) (average, 63.67\% - 13.94\% [SD]). MannWhitney U test revealed statistical significance (P-.05) between the groups of PRP patients and controls.There was no correlation between Volume of Alveolar Cleft (VAC) and Volume of Regenerated Bone (VRB) in either group. Therefore, even if the cleft waswide, the result was not necessarily poor in this study.

In the study by C Gupta Primary healing using PRP in our study was similar to other reported studies [11-13]. Although, the rate of graft rejection wasmore in group B than A, the difference was not statisticallysignificant.

Primary healing using PRP in this study was similar to otherreported studies [11-13] Although, the rate of graft rejection wasmore in group B than A, the difference was not statistically significant.

In the study conducted by Sakio et al, 2016out of the 29 patients, 26 (control group: 4; PRP group: 22) had anuneventful course postoperatively. In the 3 remaining patients(control group: 2; PRP group: 1), wound dehiscence developed with minor bone exposure. However, these exposures closed duringthe follow-up period. No other complications were observed. Oneyear postoperatively, the canine was exposed and orthodonticallyguided into 
an ideal arch relation. The concentrations of platelets of each PRP preparation and whole blood were 262.5_48.5(_103/mL) and 1514_507(_103/mL), respectively. The concentration ratio was ranged from 1.60 to 9.77 and the meaning 5.9_1.8.One month postoperative bone volume with or without PRP were 1.00_0.53

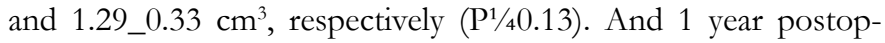
erative bone volume with or without PRP were 0.55_0.44 and $0.59 \_0.28 \mathrm{~cm} 3$, respectively ( $\mathrm{P}^{1 / 40.26}$ ) (Fig. 4). The mean resorption ratio was 49.9_17.2\% and 44.9_14.4\% with no significant difference (P1/40.60). The correlation coefficients between the PRP concentrations and resorption ratio demonstrated a week correlation of $0.35\left(\mathrm{P}^{1 / 40.08)}\right.$.

\section{Summary}

The aim of this systematic review is to assess the efficacy PRP added with the autogenous iliac bone graft in comparison with iliac graft alone. Two randomized controlled trials and one longitudinal study were included in this review. All studies have compared the iliac graft with PRP and without PRP and the quantitative bone formation was evaluated with the help of CT scans CBCT and Computer Aided Engineering.

Studies by Oyama et al,2004 and C. Gupta et al, 2011 have found a significant difference in the PRP group and the control group; However, Sakio et al, 2016 did not find significant difference in both the groups.

More studies have to be conducted to get the significant results.

\section{Conclusion}

In this systematic review after reviewing 3 articles we have concluded that, the addition of PRP to autogenous iliac bone grafts appears to significantly leads to early bone formation, reduce postoperative bone resorption, preservation the width and height of the graft, low infection rate and least post operative complications which makes the autogenous cancellous bone grafting with PRP useful for alveolar bone grafting in cleft patients.

However, studies with more sample size should be carried out. A standard method should be developed for the evaluation of the bone regeneration.

\section{References}

[1]. Boyne PJ. Secondary bone grafting of residual alveolar and palatal clefts. J Oral Surg. 1972;30:87-92.

[2]. Rychlik D, Wójcicki P. Bone graft healing in alveolar osteoplasty in patients with unilateral lip, alveolar process, and palate clefts. J Craniofac Surg. 2012 Jan;23(1):118-23.Pubmed PMID: 22337386.

[3]. Huh JY, Choi BH, Zhu SJ, Jung JH, Kim BY, Lee SH. The effect of plateletenriched fibrin glue on bone regeneration in autogenous bone grafts. Oral Surg Oral Med Oral Pathol Oral Radiol Endod . 2006 Apr 1;101(4):426-31.

[4]. van Hout WM, Mink van der Molen AB, Breugem CC, Koole R, Van Cann EM. Reconstruction of the alveolar cleft: can growth factor-aided tissue engineering replace autologous bone grafting? A literature review and systematic review of results obtained with bone morphogenetic protein-2. Clin Oral Investig. 2011 Jun;15(3):297-303.Pubmed PMID: 21465220.

[5]. Corre P, Khonsari RH, Laure B, Elamrani K, Weiss P, Mercier JM. Synthetic calcium phosphate ceramics in secondary alveoloplasty. Rev Stomatol Chir Maxillofac. 2012 Feb 4;113(2):131-5.

[6]. Singh S, Mehrotra D, Gupta C. Wide alveolar cleft and midface distraction: Report of a case. J Oral Biol Craniofac Res. 2012 May-Aug;2(2):123-5.Pubmed PMID: 25737848.
[7]. Enemark H, Krantz-Simonsen E, Schramm JE. Secondary bone grafting in unilateral cleft lip and palate patients: indications and treatment procedure. Int J Oral Surg. 1985;14:2-10

[8]. Boyne PJ. Secondary bone grafting of residual alveolar and palatal clefts. J Oral Surg. 1972;30:87-92.

[9]. Long Jr RE, Spangler BE, Yow M. Cleft width and secondary alveolar bone graft success. Cleft Palate Craniofac J. 1995 Sep;32(5):420-7.

[10]. Opitz C, Meier B, Stoll C, Subklew D. Radiographic evaluation of the transplant bone height in patients with clefts of the lip/alveolus/palate after secondary bone grafting. J Orofac Orthop. 1999;60(6):383-91.Pubmed PMID: 10605274

[11]. Marx RE, Carlson ER, Eichstaedt RM, Schimmele SR, Strauss JE, Georgeff KR. Platelet-rich plasma: Growth factor enhancement for bone grafts. Oral Surg Oral Med Oral Pathol Oral Radiol Endod 1998 Jun 1;85(6):638-46.

[12]. Härtel J, Pögl C, Henkel KO, Gundlach KK. Dental implants in alveolar cleft patients: a retrospective study. J Craniomaxillofac Surg. 1999 Dec 1;27(6):354-7.

[13]. Marukawa E, Oshina H, Iino G, Morita K, Omura K. Reduction of bone resorption by the application of platelet-rich plasma (PRP) in bone grafting of the alveolar cleft. J Craniomaxillofac Surg. 2011 Jun;39(4):278-83. Pubmed PMID: 20542707.

[14]. Sakio R, Sakamoto Y, Ogata H, Sakamoto T, Ishii T, Kishi K. Effect of Platelet-Rich Plasma on Bone Grafting of Alveolar Clefts. J Craniofac Surg. 2016 Mar;28(2):486-488.Pubmed PMID: 28033193.

[15]. Kassolis JD, Rosen PS, Reynolds MA. Alveolar ridge and sinus augmentation utilizing platelet-rich plasma in combination with freeze-dried bone allograft: case series. J Periodontol. 2000 Oct;71(10):1654-61.Pubmed PMID: 11063400

[16]. Schmitz JP, Hollinger JO. The biology of platelet-rich plasma. J Oral Maxillofac Surg. 2001 Sep 1;59(9):1119-20.

[17]. Dempf R, Teltzrow T, Kramer FJ, Hausamen JE. Alveolar bone grafting in patients with complete clefts: a comparative study between secondary and tertiary bone grafting. Cleft Palate Craniofac J. 2002 Jan;39(1):18-25.Pubmed PMID: 11772165.

[18]. Sonnleitner D, Huemer P, Sullivan DY. A simplified technique for producing platelet-rich plasma and platelet concentrate for intraoral bone grafting techniques: a technical note. Int J Oral Maxillofac Implants. 2000 NovDec;15(6):879-82.Pubmed PMID: 11151589.

[19]. Slater M, Patava J, Kingham K, Mason RS. Involvement of platelets in stimulating osteogenic activity. J. Orthop. Res. 1995 Sep;13(5):655-63.

[20]. Landesberg R, Roy M, Glickman RS. Quantification of growth factor levels using a simplified method of platelet-rich plasma gel preparation. J Oral Maxillofac Surg. 2000 Mar;58(3):297-300.Pubmed PMID: 10716112.

[21]. Luaces-Rey R, Arenaz-Búa J, Lopez-Cedrún-Cembranos JL, Herrero-Patińo S, Sironvalle-Soliva S, Iglesias-Candal E, et al. Is PRP useful in alveolar cleft reconstruction? Platelet-rich plasma in secondary alveoloplasty. Med Oral Patol Oral Cir Bucal. 2010 Jul 1;15(4):e619-23.Pubmed PMID: 20038881.

[22]. Lee C, Nishihara K, Okawachi T, Iwashita Y, Majima HJ, Nakamura N. A quantitative radiological assessment of outcomes of autogenous bone graft combined with platelet-rich plasma in the alveolar cleft. Int J Oral Maxillofac Surg. 2009 Feb;38(2):117-25.Pubmed PMID: 19147331.

[23]. MacIsaac ZM, Rottgers SA, Davit AJ 3rd, Ford M, Losee JE, Kumar AR. Alveolar reconstruction in cleft patients: decreased morbidity and improved outcomes with supplemental demineralized bone matrix and cancellous allograft. Plast Reconstr Surg. 2012 Sep;130(3):625-632.Pubmed PMID: 22929248.

[24]. Simonet WS, Lacey DL, Dunstan CR, Kelley MC, Chang MS, Lüthy R, et al. Osteoprotegerin: a novel secreted protein involved in the regulation of bone density. Cell. 1997 Apr 18;89(2):309-19.

[25]. Villela DL, Santos VL. Evidence on the use of platelet-rich plasma for diabetic ulcer: a systematic review. Growth factors. 2010 Apr 1;28(2):111-6.

[26]. Sánchez AR, Sheridan PJ, Kupp LI. Is platelet-rich plasma the perfect enhancement factor? A current review. Int J Oral Maxillofac Implants. 2003 Jan-Feb;18(1):93-103.Pubmed PMID: 12608674.

[27]. Del Fabbro M, Bortolin M, Taschieri S, Weinstein R. Is platelet concentrate advantageous for the surgical treatment of periodontal diseases? A systematic review and meta-analysis. J Periodontol. 2011 Aug;82(8):1100-11.

[28]. Sadoghi P, Rosso C, Valderrabano V, Leithner A, Vavken P. The role of platelets in the treatment of Achilles tendon injuries. J Orthop Res. 2013 Jan;31(1):111-8.

[29]. Cao X. Targeting osteoclast-osteoblast communication. Nat Med. 2011 Nov;17(11):1344-6.

[30]. Hokugo A, Ozeki M, Kawakami O, Sugimoto K, Mushimoto K, Morita $S$, et al. Augmented bone regeneration activity of platelet-rich plasma by biodegradable gelatin hydrogel. Tissue Eng. 2005 Jul-Aug;11(7-8):1224-33. Pubmed PMID: 16144458. 